\title{
Archeological Investigations at the Frank Benson Site (41TT310), Titus County, Texas
}

Timothy K. Perttula

Heritage Research Center, Stephen F. Austin State University

Bo Nelson

Heritage Research Center, Stephen F. Austin State University

Follow this and additional works at: https://scholarworks.sfasu.edu/ita

Part of the American Material Culture Commons, Archaeological Anthropology Commons, Environmental Studies Commons, Other American Studies Commons, Other Arts and Humanities Commons, Other History of Art, Architecture, and Archaeology Commons, and the United States History Commons

Tell us how this article helped you.

This Article is brought to you for free and open access by the Center for Regional Heritage Research at SFA ScholarWorks. It has been accepted for inclusion in Index of Texas Archaeology: Open Access Gray Literature from the Lone Star State by an authorized editor of SFA ScholarWorks. For more information, please contact cdsscholarworks@sfasu.edu. 


\section{Archeological Investigations at the Frank Benson Site (41TT310), Titus County,}

Texas

\section{Creative Commons License}

(c) (1) (2)

This work is licensed under a Creative Commons Attribution-NonCommercial 4.0 International License 


\title{
ARCHEOLOGICAL INVESTIGATIONS AT THE FRANK BENSON SITE (41TT310), TITUS COUNTY, TEXAS
}

\author{
Timothy K. Perttula and Bo Nelson
}

\section{Introduction}

The Frank Benson site (41TT310) is an extensive and significant prehistoric Caddo and historic $19^{\text {th }}$ century archeological site on a broad upland landform (352372 feet amsl) overlooking the Big Cypress Creek Valley in Titus County, Texas. In this paper we discuss recent archeological investigations at the site, which identified extensive and wellpreserved Middle and Late Caddo components associated with a clay mound and extensive daub deposits from at least one burned Caddo structure.

\section{Setting}

The Frank Benson site is located primarily in a well-maintained field near a day-use area at Lake Bob Sandlin State Park, on the north side of Lake Bob Sandlin. The northeasternmost parts of the site are in woods, and surface visibility across the site is less than $10 \%$.

Based on archeological work done here in 1983 by Texas Parks and Wildlife (TPW) and Prewitt and Associates, Inc. (Prikryl et al. 1984), and 2001 investigations by Archeological and Environmental Consultants (Perttula and Nelson 2002), the Frank Benson site is ex- tensive, covering approximately 32,000 square meters (about 8 acres) (Figure 1). It is by far the largest prehistoric or historic site at the state park.

The site has Bernaldo fine sandy loam sediments that range from about 10-110 $\mathrm{cm}$ in thickness (Prikryl et al. 1984:21). According to Jasinski (2001:52), there is an artesian spring on the property where the Frank Benson site is located. The spring may be located along the small intermittent tributary on the north side of the site (Figure 1), and the tributary drains north-northeast to Bell Branch. 


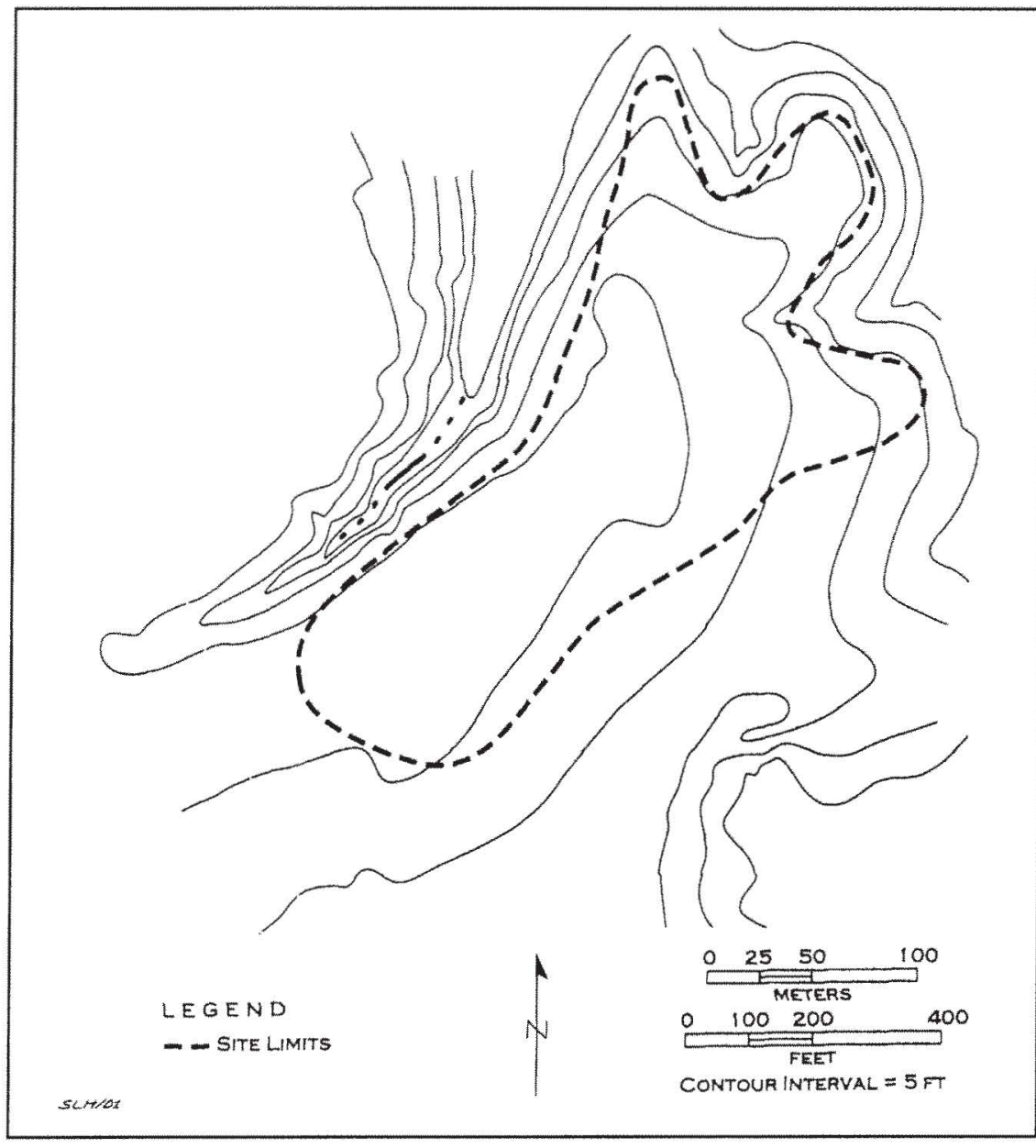

Figure 1. Overall map of the Frank Benson site (41TT310). determine if the h i s t o r i c archeological component may be associated with the Republic of Texasera Fort Sherman, TPW hired Prewitt and Associates, Inc. (PAI) to c o m p 1 e $t$ e archeological and a $\mathrm{r} c \mathrm{~h}$ i $\mathrm{v}$ a $\mathrm{l}$ investigations here. During this work, they excavated 21 $1 \mathrm{x} 1 \mathrm{~m}$ units across the site (Prikryl et al. 1984:Figure 4); T P W work consisted of four machine grader trenches, two in the central part of the site (see below) and one in the northeastern part of the site.

\section{Synthesis of 1980s Investigations}

The Frank Benson site was recorded by Ron Ralph of TPW in August 1983 (Texas Parks and Wildlife Department 1984). Ralph excavated several motor grader trenches about 200-300 $\mathrm{m}$ northwest of previously recorded site 41TT205 and uncovered archeological materials from a mid-to late $19^{\text {th }}$ century component as well as prehistoric Caddoan pottery sherds (Prikryl et al. 1984:1). To further evaluate the archeological potential of the site, and
The investigations conducted by PAI warrant a detailed review because of the significance of the archeological deposits at the Frank Benson site. As previously mentioned, PAI established that the site covers about eight acres, and there are significant and unique archeological resources of prehistoric and/or historic age in three different areas within the site boundaries: northeast (NE), southeast (SE), and central or center areas (Figure 2a). 


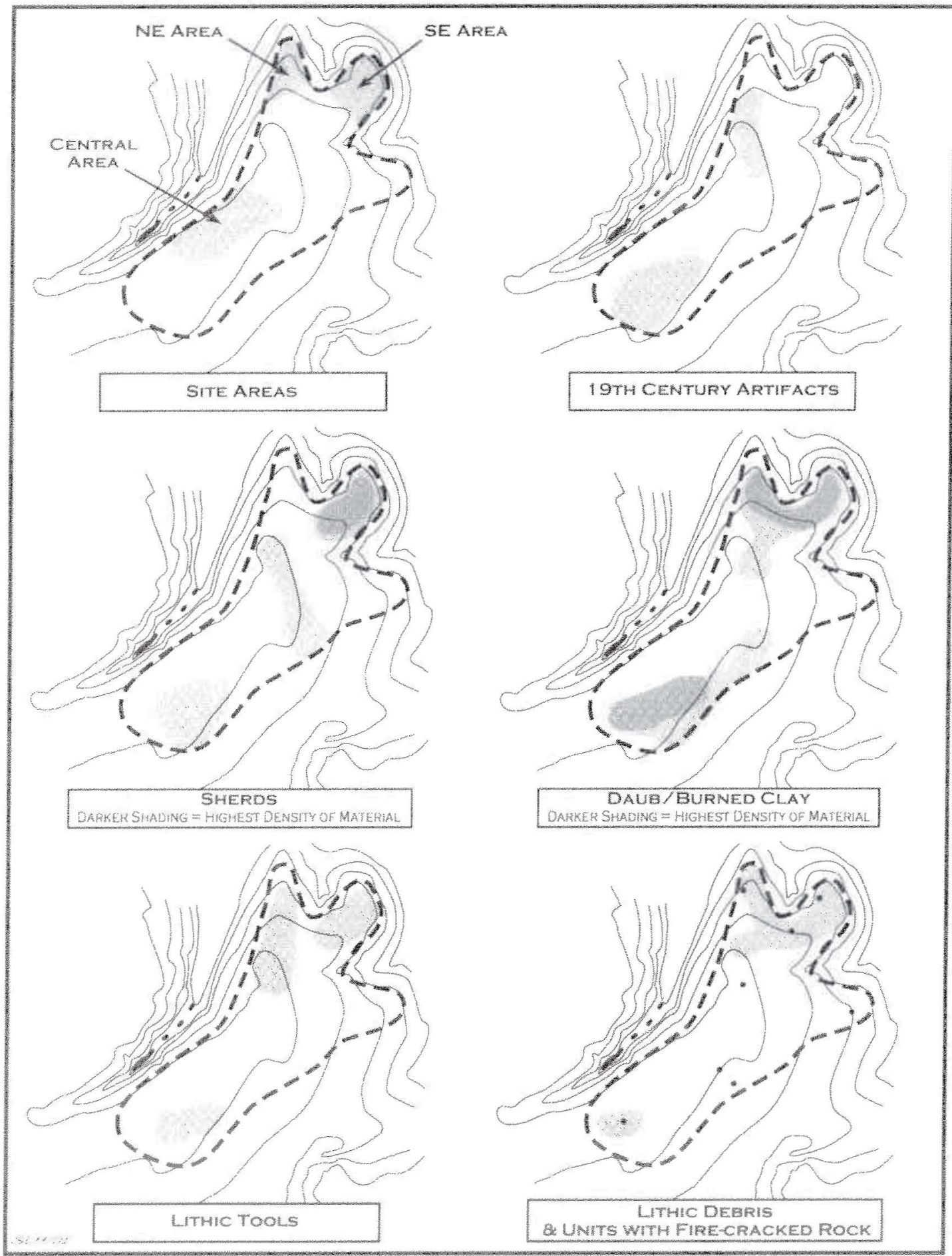

Figure 2. Spatial characteristics of the Frank Benson site: $a$, Intra-site areas; $b$, distribution of $19^{\text {th }}$ century historic artifacts; $c$, distribution of prehistoric Caddoan ceramics sherds; $d$, distribution of daub and burned clay; $e$, distribution of stone tools; $f$, distribution of lithic debris. 
The NE area is on a toe slope that drains to the north into the small Bell Branch valley. PAI work here documented both historic $19^{\text {th }}$ century and prehistoric archeological deposits, and the Archeological and Environmental Consultants work to be discussed below also identified a probable small clay-capped mound near the crest of the toe slope. The principal $19^{\text {th }}$ century archeological component is in the central or center area (Figure 2b). Hand excavations and machine grading work recovered cut nails, olive green bottle glass, shelledged whiteware, hand-painted whiteware, and stoneware sherds from a mid- $19^{\text {th }}$ century occupation. Archeological and archival investigations suggest that this area is likely the farmstead of the Frank Benson family; no structural remains or features were identified in this area, however, but we believe it is likely that such features (including pits, privy pits, and the remains of a brick or mud cat clay chimney) are still preserved here. At least some of the daub/burned clay found in the upper $20 \mathrm{~cm}$ of the archeological deposit in the central area is probably associated with a structure belonging to the historic farmstead. A small amount of similar mid$19^{\text {th }}$ century artifacts were also recovered in the NE area (Figure 2b), including shell-edged pearlware, and these may be the remnants of a second historic archeological component at the Frank Benson site.

PAl documented that there was an extensive prehistoric Caddoan occupation of the Frank Benson site. The distribution of Caddoan sherds (Figure 2c) indicate that there are concentrations of Caddoan sherds in the three separate areas, with the highest densities in what we have called the SE area (Figures $2 \mathrm{a}$ and $2 \mathrm{c}$ ). Based on differences in the proportion of brushed sherds in the three intrasite areas which is a reliable temporal measure for prehistoric Caddoan sites in the Big Cypress Creek basin (Perttula 2001b) and the different plain/decorated sherd ratios, the prehistoric Caddoan sherds are from two temporally distinct occupations.

In the central and NE areas, only $10.5 \%$ of the 19 decorated sherds are brushed, and the plain/decorated sherd ratio is 2.63 . These numbers are consistent with a Middle Caddoan period occupation, one dating probably in the $13^{\text {th }}$ century, and the recovery of red-slipped sherds here also points to a Middle Caddoan age for the prehistoric component (cf. Nelson and Turner 1997). The amount of daub and burned clay in the central area (Figure $2 \mathrm{~d}$ ), found between $30-60 \mathrm{~cm}$ bs, suggests that a buried and burned Caddoan structure is present in this part of the site, and that this area has residential Caddoan archeological deposits.

In the SE area, by contrast, $32.4 \%$ of the decorated sherds are brushed, and the plain/decorated sherd ratio is 1.29. These values indicate that the $\mathrm{SE}$ area was occupied in the Late Caddoan period, sometime after ca. A.D. 1400-1450. Daub and burned clay were also found in PAI work, and as such suggest that at least one Late Caddoan bumed structure is present in that area.

The density of daub and ceramics, and the spatial extent of the archeological deposits here, do not support the assertion 
made by Prikryl et al. (1984:59) that the use of the Frank Benson site was likely nonresidential and perhaps involved shortterm encampments by small social or task groups focusing on the procurement or processing of specific resources. Prikryl et al. (1984:59) conclusion is based primarily on a perceived limited range of activities that took place in the SE area, in particular a remarkable scarcity of cores and stone tools and the fact that most of the ceramics found here are from jars.

Based on a broader consideration of the nature of Late Caddoan archeology in the Northeast Texas Pineywoods generally, and the Big Cypress Creek area specifically (Perttula 1998, 2001a), these characteristics are not at all unusual in permanently occupied farmsteads, hamlets, and small villages of that age. Stone tools are generally limited to arrow points, celts, and flake tools, with an apparent considerable use of wood and bone tools, and little stone tool manufacture took place at such sites. For example, at the Pilgrim's Pride site (41CP304), a large Late Caddoan Titus phase village (about 10 acres in size), less than 20 stone tools were recovered in the hand and machine-excavation of about 8 acres of the settlement and in more than 500 features (Perttula 2001b). Like other Late Caddoan farming groups, the ceramics are dominated by large utility ware jars for cooking and storage functions. Fineware bowls and bottles commonly comprise less than $10-15 \%$ of the vessel sherds in Late Caddoan sites in the Big Cypress Creek basin, and the dominance of jar forms in the SE area at the Frank Benson is neither remarkable or uncharacteristic of other nearby Late Caddoan settlements.

The stone tools that were recovered in the PAI work appear to relate to earlier Archaic and Woodland period use of the Frank Benson site, except perhaps for the polished celt from the SE area. Chipped stone tools were found in the central, NE, and SE areas, and included a Neches River dart point in the central area, a Gary point (probably a var. Camden form made between ca. A.D. 200-700 [Schambach 1998], based on its stem width and thickness) from the SE area, several biface fragments, and a retouched flake tool.

Groundstone tools were also found in the three intrasite areas (Figure 2e). These included the previously mentioned ferruginous sandstone celt in the SE area, along with an abraded stone; a pigment stone in the central area, and a grinding stone in the NE area. The latter grinding stone tool was associated with a burned rock feature (Fea. 1) documented in one of the $1 \times 1 \mathrm{~m}$ units in that part of the site.

Lithic debris was concentrated in the NE and SE areas, with a smaller distribution in the central part of the site (Figure 2f). Fire-cracked rock occurred in low densities across much of the Frank Benson site, and there was a burned rock feature in the NE area. The lithic debris was dominated by locally-available raw materials, including quartzite $(67 \%)$, petrified wood $(15 \%)$, and ferruginous sandstone $(3 \%)$, and much of the chert lithic debris appeared to have been collected from local gravels. A few pieces of chert lithic debris were identified by Prikryl et al. (1984:42) as being Edwards 
chert, a non-local lithic raw material source.

Prikryl et al. (1984:62) considered the Frank Benson site, particularly the prehistoric archeological deposits, to be eligible for State Archeological Landmark nomination and potentially eligible for nomination to the National Register of
Historic Places under Criterion D (i.e., research potential). It was their opinion that the site had the potential to yield significant information towards understanding the prehistory of the Cypress Creek drainage. More recent investigations have clearly shown that their assessment of the research character of the Frank Benson site was accurate.

\section{0 and 2001 Archeological Investigations}

The next round of archeological investigations at the Frank Benson site took place in August 2000. A single shovel test (ST 14) was excavated by Cultural Resource Consultants of Houston, Texas (CRC) at the Frank Benson site, apparently in the central part of the site (which we refer to as the Central Area, below). This is one of the areas previously investigated by TPW and Prikryl et al. (1984), where substantial mid- $19^{\text {th }}$ century and some prehistoric Caddoan artifacts were recovered in test excavations (Figures 2a-2d). The one CRC shovel test had a square nail and a few pieces of charcoal (the latter not collected). Several other shovel tests were excavated by $\mathrm{CRC}$ to apparently delimit the boundaries of the site, but none of them contained any artifacts, and their exact locations are not known. Archeological and Environmental Consultants returned to the Frank Benson site in 2001, and the discussion below summarizes our findings in three different areas of the site (Figure 2a).

\section{Northeast Area}

In our 2001 investigations, 10 shovel tests were excavated in the Northeast area of the Frank Benson site, a long narrow upland ridge and toe slope (352-370 feet amsl) that covers approximately 5100 square meters (Figure 3; see also Figure 2a). The Bernaldo fine sandy loam sediments range from only ca, $13-50 \mathrm{~cm}$ in thickness here, and have abundant gravels and natural concretions. Surface visibility was less than $10 \%$ across the landform, and there was a large modern trash dump at the southeastern edge of the NE area (Figure 3).

Three different shovel tests in the Northeast area at the Frank Benson site have prehistoric artifacts found between 0 $40 \mathrm{~cm}$ bs (Figure 3 ). The artifact density is 1.00 per positive shovel test.

The most significant archeological discovery in this area is a possible claycapped mound in the southern and flatter 


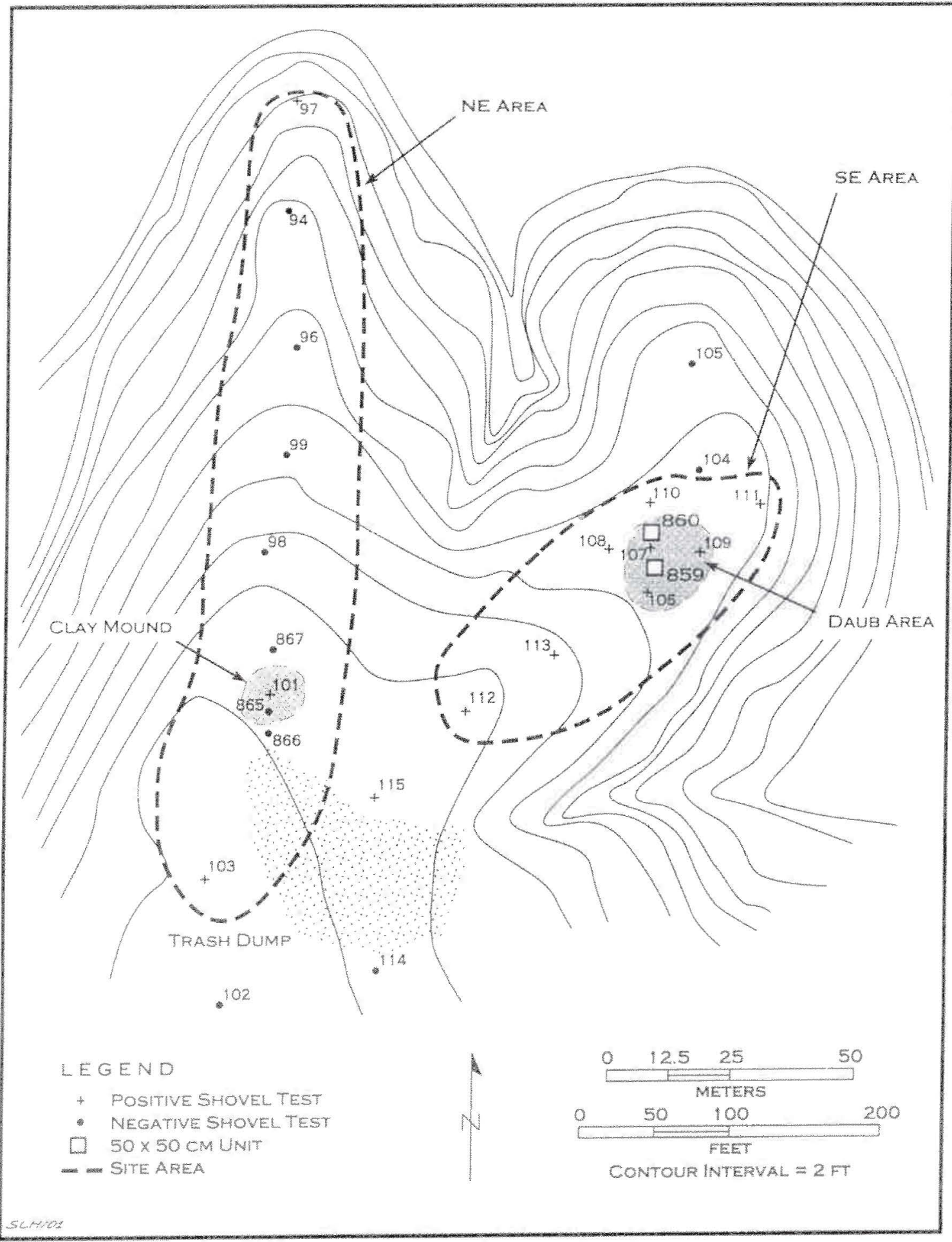

Figure 3. Map of the Northeast (NE) and Southeast (SE) areas at the Frank Benson site (4ITT310). 
part of the upland ridge and toe slope (Figure 3). Two or three shovel tests (ST 101, ST 865, and ST 867) encountered an orange clay fill or cap about $23-28 \mathrm{~cm}$ in thickness over an area approximately 11.9 $\mathrm{x} 10.7 \mathrm{~m}$ in size. The clay fill or cap overlies the A-horizon of a buried dark brown to yellowish-brown sandy loam as well as a buried B-horizon clay subsoil, and is definitely not a natural pedogenic deposit. Only a single piece of lithic debris was found in the three shovel tests, but the absence of prehistoric artifacts does not preclude the clay fill or cap being a prehistoric mound deposit. Clay caps over prehistoric Caddo structures have been documented at other Caddo sites in Northeast Texas from the Red River to the Sabine River and in the absence of further information, it is our interpretation that this clay fill or capped area represents a small prehistoric Caddoan mound. The ceramic sherds found in this general area during the earlier work by Prikryl et al. (1984) (Figure 2c, as well as the discussion above) suggests that the mound may have been built in the earlier part of the Middle Caddoan period.

The artifacts found most recently in the $\mathrm{NE}$ area include one plain ceramic body sherd (ST 103) (Figure 3) and two pieces of lithic debris. The sherd is grogtempered ( $7.0 \mathrm{~mm}$ thick), and is from a vessel fired in a reducing environment. It likely is from a post-A.D. 800 Caddo Indian vessel, based on vessel wall thickness and firing conditions. The lithic debris is Ogallala quartzite $(n=1)$ and quartzite $(\mathrm{n}=1)$. Both are non-cortical pieces, and the quartzite soft hammer flake is from a heat-treated core or tool.

\section{Central Area}

Because of the previous archeological work completed by Prikryl et al. (1984:Figure 4) and TPW in the central area, our work here consisted only of the excavation of a few shovel tests in one part (covering about 4000 square meters) of the upland landform (370 feet amsl) that had not been previously examined (Figure 4). This area is in the broad, and well-maintained field north of the day-use area at Lake Bob Sandlin State Park.

Three shovel tests in the Central area contain prehistoric ceramic and lithic artifacts between $20-80 \mathrm{~cm}$ bs (Figure 4 ). These consist of six ceramic sherds and two pieces of lithic debris. The prehistoric artifact density is 2.67 per positive shovel test, and most of the artifacts are from ST 833.

All six of the sherds are grog-tempered (mean thickness $=8.1 \mathrm{~mm}$ ), and two also have crushed hematite temper inclusions. Half of the sherds are from vessels fired in an oxidizing environment, and the others were fired in a reducing environment, but cooled in the open air. About 33\% have been smoothed on the interior vessel surface, and are probably from cooking jars.

Three body sherds, all from ST 833 (20$60 \mathrm{~cm}$ bs) are decorated. One has parallel 


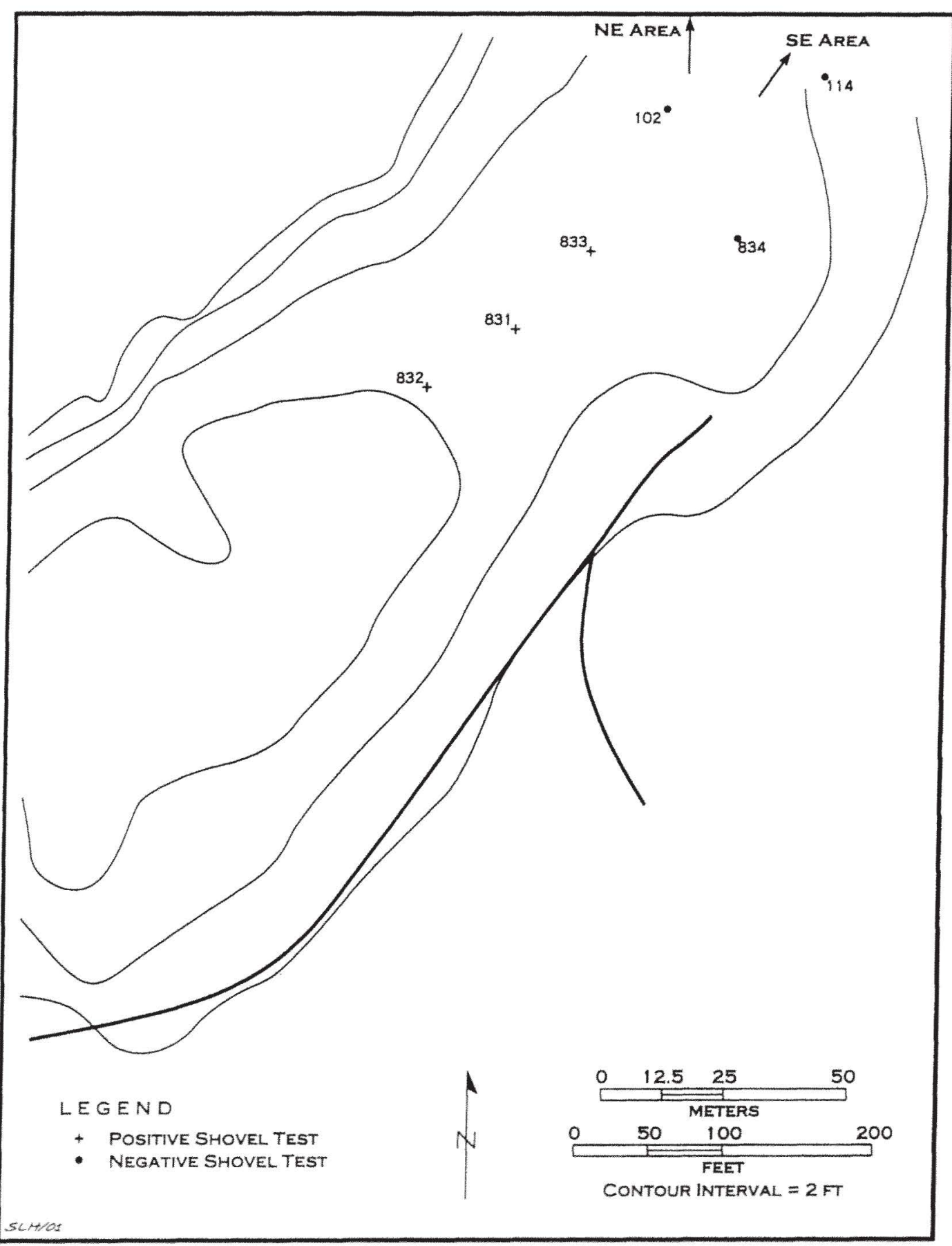

Figure 4. Map of the center area of the Frank Benson site (4ITT310). 
brushing, a second has parallel brushedincised lines, and the third has a row of fingernail punctations. Without a larger collection of decorated sherds, the temporal placement of the small sample of decorated sherds is problematic, other than to note that brushed and brushed-incised sherds are common in Middle and Late Caddoan (ca. A.D. 1200-1680) sites in the Big Cypress Creek basin.
The lithic debris is comprised of quartzite $(n=1)$ and petrified wood $(n=$ 1) raw materials, both locally available in gravel sources. The quartzite piece is a non-cortical soft hammer flake.

A single large burned mammal bone was recovered in the archeological investigations (ST 831, 20-40 cm) in this part of the Frank Benson site.

\section{Southeast Area}

The Southeast (SE) area of the Frank Benson site is located on an upland slope and toe slope (362-368 feet amsl) overlooking the small Bell Branch valley. Archeological deposits here cover approximately 2900 square meters (Figure 3). The Bernaldo fine sandy loam sediments in the SE area range from 48$110+\mathrm{cm}$ in thickness, with the shallower deposits found in both higher (i.e., ST 112 and ST 113) and lower (i.e., ST 104, ST 105 , and ST 111) parts of the landform. In the main part of the SE area, the fine sandy loam sediments are at least 100-110 $\mathrm{cm}$ in thickness (Figure 5).

Our investigations in the SE area identified a ca. $19 \times 16.7 \mathrm{~m}$ area with a significant concentration of daub pieces (Figure 3). The daub represents the burned and fired remains of clay daub and thatching (wattle) from at least one prehistoric Caddoan structure. If the overall extent of the daub concentration accurately reflects the size of the burned and buried structure in the SE area, the structure may be much larger than a typical Late Caddoan residential structure (ca. 6-8 $\mathrm{m}$ in diameter; Perttula 1998), and may be a special purpose or public structure.

As we discuss below in more detail, the daub is principally found between $20-80$ $\mathrm{cm}$ bs, with the exception of the daub in Unit 860, with the larger pieces recovered from $50-90 \mathrm{~cm}$ bs. Also, in the case of ST 107 , the densest daub deposit was between $40-50 \mathrm{~cm}$ bs. Given the landform setting of the daub area near the crest of the upland slope, it is possible that the greater depth of the daub in those two units suggests that the burned Caddoan structure may have been buried by either the natural or cultural accumulation of a substantial amount of fine sandy loam sediments.

Although no evidence of basket loading was noted, and the floor of the Caddoan structure could not be identified in the small excavation units, we consider it likely that the burned Late Caddoan structure was deliberately buried by Caddoan peoples after the structure had been left to completely burn out. Only the 


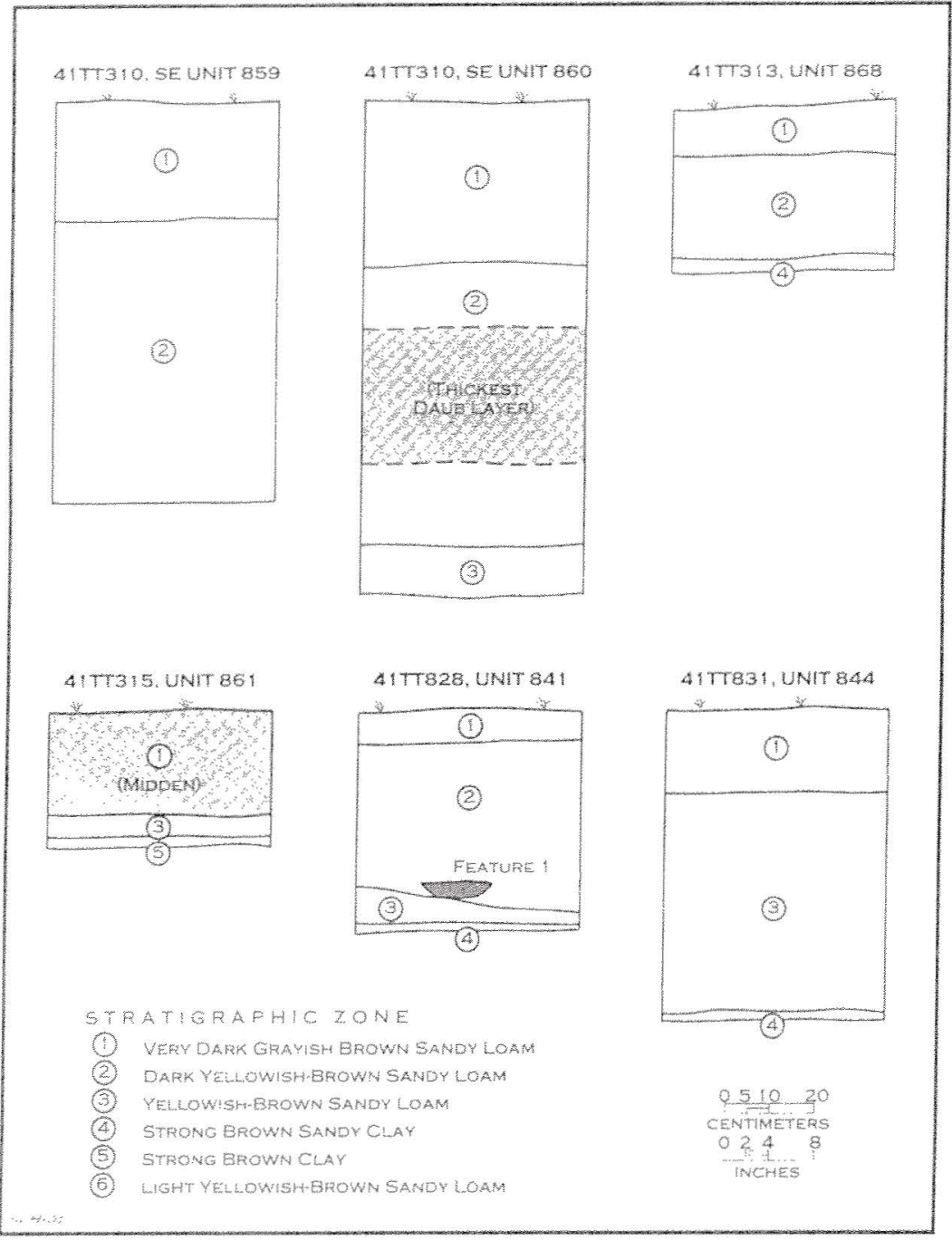

Figure 5. Selected profiles of $50 \times 50 \mathrm{~cm}$ units at Lake Bob Sandling State Park: 41TT310, SE area (units 859 and 860); 41 TT313 (unit 868); 41TT315 (unit 861); 41 TT828 (unit 841); and 41TT831 (unit 844).

the Big Cypress Creek basin. Similar daubmound deposits have been identified at the Pilgrim's Pride site (Pertula 2001b), Red $\mathrm{H}$ o n e y u c k 1 e (41CP335, Perttula et al. 1999), Camp Joy Mound (41UR144, Perttula and Nelson 2001a); the Tracy site (41CP71); the Harroun site (41UR10, Jelks and Tunnell 1959); Dalton (41UR11); S a m Roberts (41CP8, Thurmond 1990), and possibly the R. A. Watts No. 2 site (41CP14, Thurmond 1990), and there are probably others.

Oxidizable carbon ratio (OCR) dates were obtained by Archaeology Consulting Team, Inc. (Essex, Vermont) from sediments collected in Unit 860 (Figure 3) in the SE

rapid and relatively deep (ca. $40-50 \mathrm{~cm}$ ) burial of the daub would have insured that the massive and well-preserved daub deposit in the SE area would have remained as well preserved as it now is, more than 400-500 years later. Furthermore, small mounds covering massive daub accumulations from bumed Late Caddoan structures are not uncommon in area. Frink (1992, 1994, 1995, and 1999) discusses the OCR dating procedure in detail, and the OCR analyses include the identification of pedogenic markers in the soil column here, and at three other Lake Bob Sandlin State Park sites (41TT828, 41TT831, and 41TT837, see below). According to Frink, pedogenic markers are indicative of soils where pedogenic 
processes are ongoing. Such markers are evidenced by a patterning of OCR data from a column sample in the sequencing of fine particles underlying coarse soil particles; underlying elevated organic carbon content; and are mirrored by descending values of the OCR ratio and manganese and ascending $\mathrm{pH}$ values (Perttula and Nelson 2001b:29; see Perttula and Nelson 2002: Appendix 5). In general, these pedogenic markers represent turbations in the soil profile, and these turbations may be the result of cultural and/or natural processes (Frink and Dorn 2002).
The OCR dates from unit 860 are provided in Table 1. Several pedogenic markers were identified in the unit 860 column, in soil zones 1,2 , and 3 (Table 1); Zone 2 contains significant amounts of daub, and Zone 3 underlies the significant archeological deposits in this part of the $\mathrm{SE}$ area. The pedogenic markers suggest that the archeological deposits associated with the accumulation of the massive daub layer date from about A.D. 1431-1595. Radiocarbon and OCR dates from 16 other well-dated Late Caddoan Titus phase sites in the Big Cypress Creek basin, including seven Titus phase sites within 5-10 miles

Table 1. OCR Dates from the Frank Benson Site (41TT310), Unit 860.

\begin{tabular}{||l|l|l|l||}
\hline \multicolumn{1}{|c|}{ Provenience } & \multicolumn{1}{|c|}{ Soil Zone } & ACT \# & $\begin{array}{l}\text { Calculated OCR } \\
\text { Date (A.D.) }\end{array}$ \\
\hline \hline $8-10 \mathrm{~cm}$ bs & Zone 1 & 5299 & A.D. 1623-1641 \\
$18-20 \mathrm{~cm}$ bs & Zone 1 & 5300 & A.D. 1589-1609 \\
$28-30 \mathrm{~cm}$ bs & Zone 1 & 5301 & A.D. 1575-1595 \\
$38-40 \mathrm{~cm}$ bs & Zone 2 & 5302 & A.D. 1552-1574 \\
$48-50 \mathrm{~cm}$ bs & Zone 2 & 5303 & A.D. 1524-1548 \\
$58-60 \mathrm{~cm}$ bs & Zone 2 & 5304 & A.D. 1494-1520 \\
$68-70 \mathrm{~cm}$ bs & Zone 2 & 5305 & A.D. 1481-1507 \\
$78-80 \mathrm{~cm}$ bs & Zone 2 & 5306 & A.D. 1449-1477 \\
$88-90 \mathrm{~cm}$ bs & Zone 2 & 5307 & A.D. 1431-1461 \\
$98-100 \mathrm{~cm}$ bs & Zone 3 & 5308 & A.D. 1411-1441 \\
$108-110 \mathrm{~cm}$ bs & Zone 3 & 5309 & A.D. 1396-1428 \\
\hline
\end{tabular}

Note: underlined and bolded OCR Dates are from specific pedogenic markers in the soil column 
of Lake Bob Sandlin State Park, indicate that the Titus phase dates from ca. A.D. 1430-1640 (Perttula and Nelson 2001a: Figure 11). The prehistoric Caddoan occupation in the SE area at the Frank Benson site appears to have been by Titus phase Caddoan peoples.

An impressive range of prehistoric archeological materials were recovered in the most recent survey investigations at the Frank Benson site, including faunal remains and charred plant remains. Eight shovel tests and $250 \times 50 \mathrm{~cm}$ units (\#859 and 860) contain prehistoric artifacts from $0-110 \mathrm{~cm}$ bs (Figure 3), with much of the materials concentrated from $20-80 \mathrm{~cm}$ bs. With respect to the ceramic artifacts, not including the daub (see below) or the sherdlets, about $70 \%$ of the plain and decorated sherds were found between 20 $80 \mathrm{~cm} \mathrm{bs}$, and $55 \%$ of the lithic artifacts were found from the same depths. About $31 \%$ of the lithic artifacts, however, were recovered from $80-110 \mathrm{~cm}$ bs, compared to only $10 \%$ of the sherds, suggesting that an earlier component (perhaps Woodland period in age, based on the recovery of a Gary dart point by Prikryl et al. [1984]) with few sherds may be deeply buried at the site.

The artifact density is 8.63 per positive shovel test and 200.0 artifacts per square meter in the $50 \times 50 \mathrm{~cm}$ units. The highest densities of ceramic sherds are in unit 860 , ST 108, ST 107, ST 106, and unit 859 (Figure 3), in that order, with densities ranging between $\mathrm{ca}$. 48-156 sherds per square meter, respectively. The higher lithic artifact densities are found in unit
860, unit 859, and ST 106, ST 108, ST 109, and ST 110, in that order, with densities ranging between 45-120 lithics per square meter.

There are 61 sherds and 34 sherdlets in the Frank Benson ceramic assemblage. The 61 sherds include 32 plain sherds (including two rims from ST 109) and 29 decorated sherds. The plain/decorated sherd ratio is 1.10 , which suggests that the prehistoric Caddoan occupation took place after ca. A.D. 1400/1450 (Perttula 2001c); this is consistent with the OCR dates from the unit 860 column (Table 1). Other dated Late Caddoan sites in the middle Sabine River basin, the Cypress Creek basin, and the Neches-Angelina basins in Northeast Texas have plain/decorated sherd ratios that range between 1.30-0.50. About 95\% of the sherds have grog temper, either as the sole temper inclusion or in combination with hematite $(43 \%)$ or bone $(23 \%)$. One sherd has only crushed bone temper, another has hematite temper, and a third sherd has both bone and hematite pieces. Almost $20 \%$ of the sherds are from vessels made with a naturally sandy clay. Analysis of firing conditions (cf. Teltser 1993) indicate that about $69 \%$ of the sherds are from vessels fired in a reducing environment, and these are roughly equally split between those cooled in the open air versus those left to cool in the fire. The remainder of the sherds are from vessels fired in an oxidizing environment $(8.6 \%)$ or incompletely oxidized during firing $(22.3 \%)$.

The 29 decorated sherds include four rims and 25 body sherds. Ten body sherds 


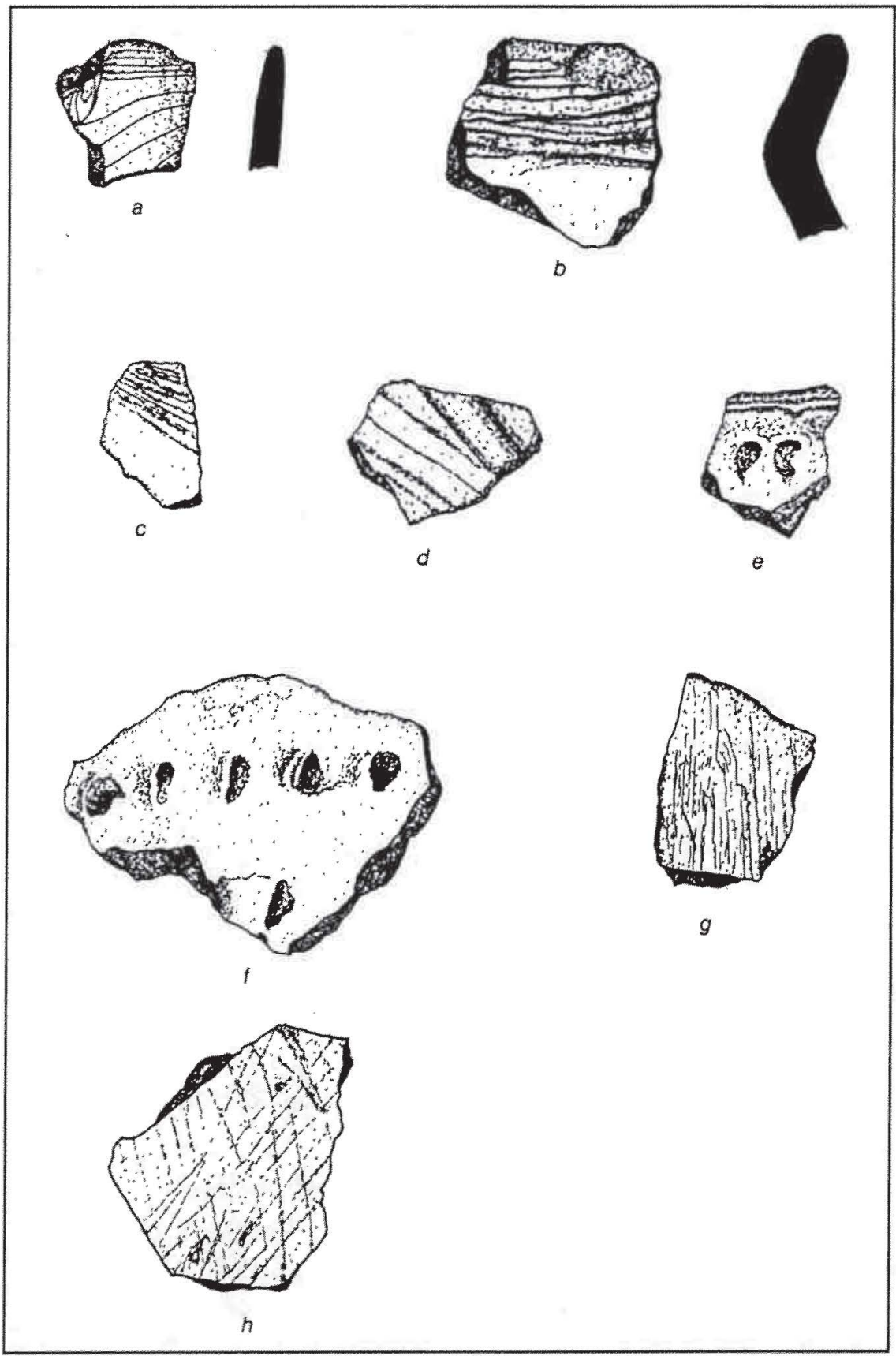

Figure 6. Decorated sherds from the Frank Benson site: a) diagonal incised with a rim peak (unit $860,20-30 \mathrm{~cm}$ ); b) horizontal incised rim (unit $860,70-80 \mathrm{~cm}$ ): c) engraved body sherd (unit $860,70-80 \mathrm{~cm}$ ): d) parallel incised (ST 108, 40-60 cm); 3) incised-tool punctated (ST 112, $20-40 \mathrm{~cm}) ; \mathrm{f}$, fingernail punctated (ST 109, 0-20 cm); g), parallel brushed (unit 860,90-100 cm); h, overlapping brushed (ST 109, 40-60 (m). have parallel brushed decorations (Figure 6g), and two others have overlapping brushed decorations (Figure 6h). Including one other sherd that has a parallel brushedincised decoration, $44.8 \%$ of the decorated sherds from the Frank Benson site have brushing. The proportion of brushed sherds is consistent with a Late Caddoan ceramic assemblage. For instance, at the nearby Pilgrim's Prid e sit e (41CP304), with a Titus phase occupation that dates between ca. A.D. 1430-1600, $49 \%$ of the 3952 decorated sherds have brushing (Perttula 2001b).

Also common are fingernail punctated $(n=5)$ and tool punctated $(\mathrm{n}=1)$ body and rim sherds (Figure 6f), with the punctates arranged in rows or lines 
along the rim or up and down the vessel body. Another sherd has an incisedpunctated decoration (Figure 6e). This particular sherd has a broad incised line next to a row of tool punctations; the orientation of the incised line is uncertain, but it may have been horizontal, with the punctations at the rim-body juncture, or diagonal, with the punctations in rows within a triangular incised zone. Other incised sherds include body sherds with parallel and broadly spaced incised lines $(n=3)$ (Figure 6d), two rims with sets of horizontal incised lines (Figure 6b), another rim with finely executed diagonal lines (Figure 6a), and one body sherd with a single incised line from an indeterminate decorative element. The diagonal incised rim also has a small rim peak (Figure 6a), suggesting it is from a bowl.

There are two engraved sherds, one from a carinated bowl and the other from a bottle. The carinated bowl sherd has a set of opposed lines, probably part of a triangular decorative element (Figure 6c), and a red hematite-rich pigment has been smeared in the engraved lines. The vessel sherd has also been smoothed on its exterior surface, which is a common surface treatment on bowls and other fine wares (i.e., bottles and red-slipped vessels). The engraved bottle sherd (ST $108,80-100 \mathrm{~cm}$ bs) has broadly-spaced parallel engraved lines on the vessel body. This vessel is grog-tempered, fired in a reducing environment, and well smoothed on its exterior surface.

The two plain rims have rounded, but exterior folded lips, and are probably from the same vessel (ST 109, 60-80 and 80$100 \mathrm{~cm}$ bs). The vessel was tempered with grog and fired in a reducing environment; the rim is only $4.6-4.7 \mathrm{~mm}$ thick, suggesting the vessel is a bowl or serving vessel rather than a cooking vessel, as the latter have thicker vessel walls.

As previously mentioned, substantial amounts of daub were recovered from six shovel tests and two $50 \times 50 \mathrm{~cm}$ units in the Southeast area, all concentrated in a ca. 320 square meter locale (Figure 3). The abundance of daub, and many large pieces, indicate that a burned Caddo Indian house structure stood in this part of the site.

There are 2803 pieces of daub, weighing $4576.0 \mathrm{~g}$ (Table 2). On average, each piece of daub weighs 1.63 grams, but many daub pieces, particularly from the deeper parts of the archeological deposit, weigh more than 20-50 g each and are hand and fist-sized (Figure 7). In ST 107, the daub is concentrated between $20-80 \mathrm{~cm}$ bs, with the largest pieces in the $20-60 \mathrm{~cm}$ levels (Table 2). Here, the density of daub is approximately $22 \mathrm{~kg}$ per square meter and more than 14,800 pieces of daub per square meter, and the daub was concentrated in a distinct and compact lens, as if the Caddo structure fell over and collapsed. In unit 860 , the daub is concentrated between $20-100 \mathrm{~cm}$ bs, with the densest and largest pieces between 50 $90 \mathrm{~cm}$ bs (Table 2). Daub densities are not as high as detected in ST 107, with approximately $9 \mathrm{~kg}$ per square meter and more than 5000 pieces of daub per square meter. 
Table 2. Distribution of Daub at the Frank Benson Site (41TT310), SE Area.

\begin{tabular}{|c|c|c|c|}
\hline Provenience & \# of daub & Weight of daub (g) & Mean weight of daub (g) \\
\hline STI $106,0-20 \mathrm{~cm}$ & 14 & 13.3 & 0.95 \\
\hline $20-40 \mathrm{~cm}$ & 10 & 11.5 & 1.15 \\
\hline $40-60 \mathrm{~cm}$ & 4 & 4.0 & 1.00 \\
\hline$S T 107,0-20 \mathrm{~cm}$ & 27 & 30.7 & 1.14 \\
\hline $20-40 \mathrm{~cm}$ & 361 & 612.0 & 1.69 \\
\hline $40-60 \mathrm{~cm}$ & 543 & 948.6 & 1.73 \\
\hline $60-80 \mathrm{~cm}$ & 421 & 456.4 & 1.08 \\
\hline ST108, 20-40 cm & 1 & 2.5 & 2.50 \\
\hline $40-60 \mathrm{~cm}$ & 1 & 4.8 & 4.80 \\
\hline ST $109,0-20 \mathrm{~cm}$ & 3 & 4.8 & 1.60 \\
\hline $20-40 \mathrm{~cm}$ & 6 & 5.8 & 0.97 \\
\hline $40-60 \mathrm{~cm}$ & 4 & 8.5 & 2.13 \\
\hline $60-80 \mathrm{~cm}$ & 3 & 3.6 & 1.20 \\
\hline $\mathrm{ST} 110,0-20 \mathrm{~cm}$ & 5 & 5.3 & 1.06 \\
\hline $20-40 \mathrm{~cm}$ & 3 & 10.9 & 3.63 \\
\hline $40-60 \mathrm{~cm}$ & 2 & 8.1 & 4.05 \\
\hline $\mathrm{ST} 111,0-20 \mathrm{~cm}$ & 1 & 0.60 & 0.60 \\
\hline Unit $859,0-10 \mathrm{~cm}$ & 13 & 9.1 & 0.70 \\
\hline $10-20 \mathrm{~cm}$ & 10 & 7.6 & 0.76 \\
\hline $20-30 \mathrm{~cm}$ & 31 & 33.3 & 1.07 \\
\hline $30-40 \mathrm{~cm}$ & 30 & 45.8 & 1.53 \\
\hline $40-50 \mathrm{~cm}$ & 11 & 15.2 & 1.38 \\
\hline $50-60 \mathrm{~cm}$ & 7 & 20.1 & 2.86 \\
\hline $60-70 \mathrm{~cm}$ & 6 & 7.7 & 1.28 \\
\hline $70-80 \mathrm{~cm}$ & 0 & - & - \\
\hline $80-90 \mathrm{~cm}$ & 4 & 9.8 & 2.45 \\
\hline Unit $860,0-10 \mathrm{~cm}$ & 20 & 15.5 & 0.78 \\
\hline $10-20 \mathrm{~cm}$ & 40 & 30.6 & 0.77 \\
\hline $20-30 \mathrm{~cm}$ & 85 & 94.5 & 1.11 \\
\hline $30-40 \mathrm{~cm}$ & 184 & 114.3 & 0.62 \\
\hline $40-50 \mathrm{~cm}$ & 119 & 147.2 & 1.24 \\
\hline $50-60 \mathrm{~cm}$ & 111 & 327.9 & 2.95 \\
\hline $60-70 \mathrm{~cm}$ & 255 & 605.7 & 2.37 \\
\hline $70.80 \mathrm{~cm}$ & 189 & 450.6 & 2.38 \\
\hline $80-90 \mathrm{~cm}$ & 164 & 383.8 & 2.34 \\
\hline $90-100 \mathrm{~cm}$ & 65 & 104.6 & 1.61 \\
\hline $100-110 \mathrm{~cm}$ & 49 & 19.8 & 0.40 \\
\hline
\end{tabular}




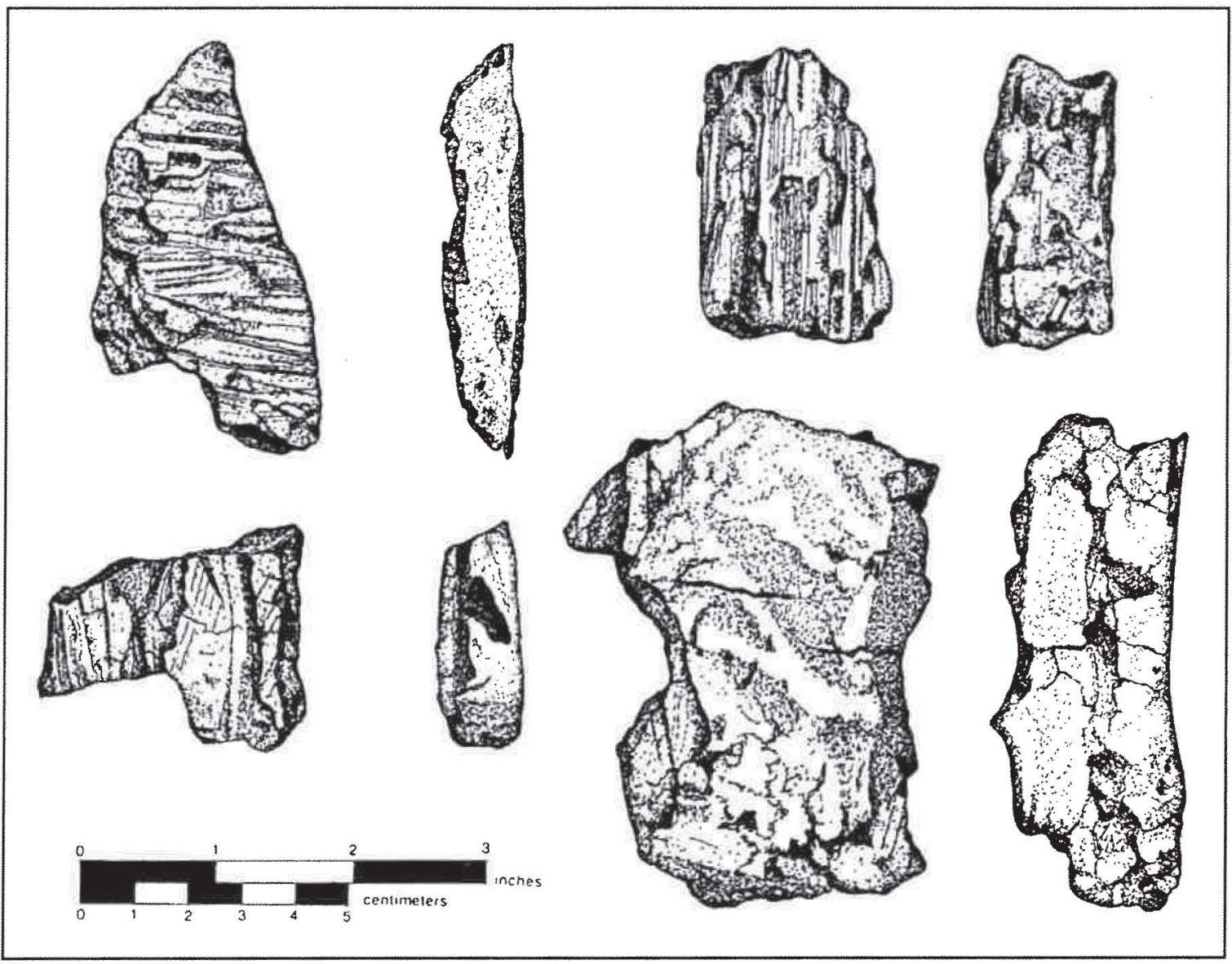

Figure 7. Daub from the SE area at the Frank Benson site (4ITT310).

The lithic artifact assemblage includes four tools, four pieces of fire-cracked rock, and 65 pieces of lithic debris. The four tools were found between $40-110 \mathrm{~cm}$ bs in ST 109 and units 859 and 860 (Figure 3). Two are flake tools, a third is the tip to an arrow point, and the last appears to be an arrow point preform. The first flake tool (ST 109, 40-60 cm bs) has bilateral use-wear (totaling $35 \mathrm{~mm}$ in length) on a non-cortical soft hammer flake of reddish-yellow chert; the tool is $21.5 \times 19 \times 4.0 \mathrm{~mm}$ in length, width, and thickness. The other flake tool (unit 859,
$50-60 \mathrm{~cm} \mathrm{bs}$ ) is a small fragment of a quartzite flake (heat-treated) with unilateral use-wear; the remnant of usewear extends $8.5 \mathrm{~mm}$ along one edge of the flake fragment. The arrow point tip (ST 109, 60-80 cm bs) is unifacially worked and only $1.9 \mathrm{~mm}$ thick. It has been made on a heat-pocked flake of gray chert. The ovoid preform (unit $860,100-110 \mathrm{~cm}$ ) of Ogallala quartzite (heat-treated) was shaped by soft hammer flaking, but has a thick knot of material on one face that could not be removed, and the piece was apparently discarded. It is $26 \times 21 \times 6.5$ 
$\mathrm{mm}$ in length, width, and thickness.

The lithic debris is represented by a high diversity in raw materials, including the more abundant quartzite $(n=23,35.4 \%$ cortical), petrified wood $(\mathrm{n}=10,80 \%$ cortical), gray chert $(n=10,20 \%$ cortical $)$, Ogallala quartzite $(\mathrm{n}=8,13 \%$ cortical), light gray chert $(n=4,25 \%$ cortical), and novaculite $(n=3)$. Raw materials with one or two pieces of lithic debris are a dark gray chert $(\mathrm{n}=2,50 \%$ cortical), yellowish-gray chert $(n=1,100 \%$ cortical), ferruginous sandstone $(n=1,100 \%$ cortical), dark reddish-gray chert $(n=1)$, claystone/siltstone $(\mathrm{n}=1)$, and quartzitic sandstone $(n=1)$. The only clearly nonlocal raw materials in the lithic debris are novaculite, claystone/siltstone, and the quartzitic sandstone, all available in Red River gravels (Banks 1990). These account for $7.7 \%$ of the lithic debris. No Edwards chert was identified in the present lithic debris sample. The remainder of the lithic debris is likely from local gravel sources, either in upland gravel deposits or along Big Cypress Creek.

A total of $35.4 \%$ of the lithic debris has cortical remnants (proportionally, the highest cortical frequencies are $80 \%$ of the petrified wood flakes and $35.4 \%$ of the quartzite flakes), and $41.5 \%$ are heattreated; this includes $82.6 \%$ of the coarsegrained quartzite, $88 \%$ of the Ogallala quartzite, and $33 \%$ of the novaculite. Sixty percent of the identifiable flakes are of the soft hammer type, and soft hammer flakes are prevalent in the quartzite, Ogallala quartzite, and gray chert lithic debris, while the light gray chert flakes are hard hammer flakes. Clearly all stages of lithic reduction occurred at the Frank Benson site, including cortex removal (especially the quartzite and petrified wood materials, but also some of the small cobbles/pebbles of local chert), heat treatment of the coarser quartzites to improve their knappability, reduction activities to produce usable flakes for tools, and billet flaking to shape and finish lithic tools.

The one quartzitic sandstone flake (unit $859,40-50 \mathrm{~cm} \mathrm{bs}$ ) has remnants of polishing on its obverse face, and is probably a celt resharpening flake. The ferruginous sandstone flake fragment (unit 860, 80-90 $\mathrm{cm}$ bs) may be the product of shaping or reshaping a groundstone tool, since this raw material was preferred by the Caddo and other aboriginal inhabitants of Northeast Texas for grinding slabs, pitted stones, and metates/mortars.

The fire-cracked rock was found in ST 106 , ST 111, and unit 859, all at shallow depths $(0-40 \mathrm{~cm}$ bs). The pieces of ferruginous sandstone and quartzite weigh $570 \mathrm{~g}$. They may be the remnants of hearths or cooking features, or based on their shallow depth, they may be unrelated to much of the prehistoric occupation and could have been collected in the sandy sediments that appear to have been dumped atop the burned Caddo house structure after the fire had died out there.

Investigations here found 32 pieces of animal bone - mammal, large mammal, and medium-sized artiodactyl - in the SE area of the Frank Benson site (Perttula and Nelson 2002:Appendix 6). These were 
concentrated in Unit 859 and Unit 860 excavated in the area of the burned prehistoric Caddo Indian house structure (Figure 3).

Charred plant remains were recovered from seven shovel tests and both $50 \times 50$ $\mathrm{cm}$ units in the Southeast area of the Frank
Benson site (Perttula and Nelson 2002: Appendix 7). This includes pine wood charcoal (2.2 g), oak wood charcoal (0.8 $\mathrm{g})$, hickory wood charcoal $(0.3 \mathrm{~g})$, yaupon (Ilex sp.) wood charcoal (0.1 g), willow/ cottonwood wood charcoal (Salicaceae) $(0.1 \mathrm{~g})$, walnut nut shell $(0.3 \mathrm{~g})$, and hickory nutshells and nut meat $(2.0 \mathrm{~g})$.

\section{Concluding Comments}

The Frank Benson site (41TT310) has important and well-preserved residential and civic-ceremonial archeological deposits of Middle (ca. A.D. 1200-1400) and Late Caddoan (ca. A.D. 1400-1680) age. Identified to date in these deposits are several impressive concentrations of daub that appear to mark the locations of burned clay and thatch-lined prehistoric Caddo Indian structures, a clay mound (that may cap another structure), and a diverse assemblage of ceramic, lithic, animal, and plant remains that represent the discarded products of everyday life from several generations of Caddo farmers that settled in the Pineywoods along Big Cypress Creek in present-day Northeast Texas. During Late Caddoan times, the Frank Benson settlement was part of a closely-associated series of Titus phase communities that lived across more than $11,000 \mathrm{~km}^{2}$ in the region, and farmed and hunted in the Big Cypress Creek valley and along its principal tributaries. Some 250 years after the site was abandoned by the Caddo, Frank Benson settled here and farmed for a few years before the Civil War and built a log cabin.

\section{Acknowledgments}

We would like to thank Sandy Hannum and Nancy Reese for preparing the maps and artifact illustrations, respectively, used in this paper.

\section{References Cited}

Banks, L. D.

1990 From Mountain Peaks to Alligator Stomachs: A Review of Lithic Sources in the Trans-Mississippi South, the Southern Plains, and Adjacent Southwest. Memoir \#4. Oklahoma Anthropological Society, Norman. 
Frink, D. S.

1992 The Chemical Variability of Carbonized Organic Matter through Time. Archaeology of Eastern North America 20:67-79.

1994 The Oxidizable Carbon Ratio (OCR): A Proposed Solution to Some of the Problems Encountered with Radiocarbon Data. North American Archaeologist 15(1):17-29.

1995 Application of the Oxidizable Carbon Ratio Dating Procedure and its Implications for Pedogenic Research. In Pedological Perspectives in Archaeological Research, pp. 95-106. SSSA Special Publication No. 44. Soil Science Society of America, Madison, Wisconsin.

1999 The Scientific Basis of Oxidizable Carbon Ratio (OCR) Dating. SAA Bulletin $17(5): 32-37$.

Frink, D. S., and R. I. Dorn

2002 Beyond Taphonomy: Pedogenic Transformations of the Archaeological Record in Monumental Earthworks. Journal of the Arizona-Nevada Academy of Science $34(1): 24-44$.

Jasinski, L.

2001 A History of Lake Bob Sandlin State Park. MS on file, Cultural Resources Program, Texas Parks and Wildlife, Austin.

Jelks, E. B., and C. D. Tunnell

1959 The Harroun Site: A Fulton Aspect Component of the Caddoan Area, Upshur County, Texas. Archaeology Series No. 2. Department of Anthropology, The University of Texas at Austin.

Nelson, B., and M. Turner

1997 Middle Caddoan Sites in the Cypress Creek Drainage Basin. Journal of Northeast Texas Archaeology 10:1-11.

Perttula, T. K.

1998 Late Caddoan Societies in the Northeast Texas Pineywoods. In Caddoan Native History: Their Place in Southeastern Archeology and Ethnohistory, edited by T. K. Perttula and J. E. Bruseth, pp. 69-90. Studies in Archeology 30. Texas Archeological Research Laboratory, The University of Texas at Austin. 
2001a The Prehistoric and Caddoan Archeology of the Northeast Texas Pineywoods. In The Prehistoric Archeology of Texas, edited by T. K. Perttula. Texas A\&M University Press, College Station, in press.

$2001 \mathrm{~b}$ (editor) Archeological Investigations at the Pilgrim's Pride Site (41CP304), A Titus Phase Center in the Big Cypress Creek Basin. Review draft. 2 Vols. Report of Investigations No. 30. Archeological and Environmental Consultants, Austin.

2001c Ceramic Artifacts. In Results of National Register Investigations Conducted on Site 41PN175, Panola County, Texas, by M. B. Cliff, pp. 59-81. Document No. 010242, PBS\&J, and Archeological Studies Program, Report No. 21, Environmental Affairs Division, Texas Department of Transportation, Austin, in press.

Perttula, T. K., and B. Nelson

2001a Archeological Investigations at the Camp Joy Mound (41UR144): A Titus Phase Earthen Mound Site at Lake O' the Pines, Upshur County, Texas. Report of Investigations No. 44. Archeological and Environmental Consultants and Friends of Northeast Texas Archaeology, Austin and Pittsburg.

2001b Archeological Test Excavations at the Prestonwood (41SM272) and Broadway (41SM273) Sites Along the City of Tyler-Lake Palestine WTP Project, Smith County, Texas. Report of Investigations No. 43. Archeological and Environmental Consultants, Austin.

2002 Archeological Survey of Lake Bob Sandlin State Park, Titus County, Texas. Report of Investigations No. 48. Archeological and Environmental Consultants, Austin.

Perttula, T. K., B. Nelson, and B. Gonzalez

1999 Archeological Survey of a Proposed Housing Area Complex in the Walker Creek Project Area for Pilgrim's Pride Corporation, Camp County, Texas. Report of Investigations No. 28. Archeological and Environmental Consultants, Austin.

Prikryl, D. J., K. Gilmore, R. C. Fields, and N. G. Reese

1984 Archeological and Archival Investigations at 41 TT310, Lake Bob Sandlin State Park, Titus County, Texas. Reports of Investigations No. 27. Prewitt and Associates, Inc., Austin.

Schambach, F. F.

1998 Pre-Caddoan Cultures in the Trans-Mississippi South: A Beginning Sequence. Research Series No. 53. Arkansas Archeological Survey, Fayetteville. 
Teltser, P. A.

1993 An Analytic Strategy for Studying Assemblage-Scale Ceramic Variation: A Case Study from Southeast Missouri. American Antiquity 58(3):530-543.

Texas Parks and Wildlife Department

1984 Master Plan and Site Analysis for Lake Bob Sandlin State Recreation Area, Titus County, Texas. Texas Parks and Wildlife Department, Austin.

Thurmond, J. P.

1990 Archeology of the Cypress Creek Drainage Basin, Northeastern Texas and Northwestern Louisiana. Studies in Archeology 5. Texas Archeological Research Laboratory, The University of Texas at Austin. 